\title{
Experimental and economical study of sustainable electricity generation by solar PV/diesel hybrid systems without storage for off grid areas
}

\author{
D. Yamegueu ${ }^{1,2}$, Y. Azoumah ${ }^{1} \&$ X. $\mathrm{Py}^{2}$ \\ ${ }^{1}$ Laboratoire Energie Solaire et Economie d'Energie (LESEE), \\ Institut International d'Ingénierie de l'Eau et de l'Environnement (2iE), \\ Ouagadougou, Burkina Faso \\ ${ }^{2}$ Laboratoire PROcédés, Matériaux et Energie Solaire (PROMES), \\ Université de Perpignan Via Domitia, Perpignan, France
}

\begin{abstract}
This paper presents the results of an experimental study of a PV/diesel hybrid system without storage. The results obtained show that the sizing of a PV/diesel hybrid system, by taking into account the solar radiation and the load/demand profile of a typical area, must permit the diesel generator to operate near its optimal point $(70-90 \%$ of its nominal power). It has been verified that the reliability of the system necessitates that the diesel generator be sized to meet the peak-load demand in case of transient cloud and in the evening. Also, a comparative analysis for three different systems (diesel and solar PV generators only, and hybrid solar PV/diesel system) for powering a same load profile has been made and shows that the hybrid system is more cost-efficient than the two others. These results show that there is a possibility to increase the electrification rate in remote areas by the implementation of hybrid solar PV/diesel systems. Keywords: hybrid system, photovoltaic, diesel, electrification, off-grid areas.
\end{abstract}

\section{Introduction}

The electrification rate in sub-Saharan Africa is lower than in any region of the world. Indeed, more than $70 \%$ of the populations of this region are excluded from the benefits linked to the electricity. The situation is more catastrophic in 
rural areas where less than $12 \%$ of the populations have access to electricity [1]. In many cases, the utility grid extension is quite unconceivable because of population dispersion, rugged terrain or both [2] and mainly because of the high investment costs of transmission and distribution lines. Thus, in these areas far from any existing grids, the supply of electricity is achieved using stand alone power systems and broadly by diesel generators (DG). However, the volatile prices of fossil fuels, the very high maintenance cost of diesel generators coupled with the environmental and climate change concerns make this option unsustainable. Fortunately, most of the developing countries and specially those of sub Saharan Africa region have a high potential in renewable energy resources such as wind, hydropower, biomass and solar that could help in raising their access to energy, and then their economic development.

In order to contribute to the increase of the electrification rate in sub-Saharan Africa, an original "flexy energy" concept of hybrid solar PV/diesel/biofuel power plant, without battery storage, has been developed by Azoumah et al. [3]. To assess the technical and economical feasibility of this concept, a PV/diesel hybrid system without storage has been set up on the site of the International Institute for Water and environmental engineering (2iE) at Kamboinsé $\left(12^{\circ} 22^{\prime} \mathrm{N}\right.$ and $\left.1^{\circ} 31^{\prime} \mathrm{W}\right)$, locality situated at fifteen kilometers to the North of Ouagadougou, capital of Burkina Faso. This prototype consists of a PV array of $2.85 \mathrm{kWp}$ coupled with a $9.2 \mathrm{~kW}$ diesel generator. The concern of this paper is to present the obtained technical performances of the hybrid facility under various operating conditions. Four fixed load/demand profiles corresponding to different percentages of the nominal capacity of the diesel generator have been experimented for obviously different solar radiations and consequently various PV contributions. The obtained raw and calculated performances are presented and discussed in this paper. Also, a comparative analysis for three different systems (diesel and solar PV generators only, and hybrid solar PV/diesel system) for powering a same load profile has been made and shows that the hybrid system is more cost-efficient than the two others.

\section{An overview on hybrid renewable energy systems}

In the open literature, many studies are based on hybrid renewable energy systems (HRES) [4-6]. The term hybrid renewable energy system is used to describe any energy system composed of more than one type of generator. The usual configuration is made of a conventional diesel powered generator associated to a renewable energy source such as PV, wind, or even PV/wind, in most case incorporating battery storage. The battery storage permit to meet the demand when either the demand is a peak load demand or when renewable energy source is not sufficient to meet the load. However, the batteries present major drawbacks as: additional investment and maintenance costs and extra costs due to periodic replacement induced by reduced lifetime [7, 8]. As a matter of fact, the cost of batteries can represent up to 16 to $20 \%$ of the total life cycle of a hybrid PV/diesel/battery system $[9,10]$ and up to $40 \%$ of the total system costs for only a PV system [11]. Besides, in developing countries, such as those of the 
sub Saharan Africa region, there is no policy concerning recycling of batteries at the end of their lifetime. This particular aspect represents a considerable environmental problem. According to all these above reasons, some authors have studied the case of PV/diesel hybrid system without storage [12, 13]; but these studies were limited to the feasibility aspects and then, there is no available experimental result from a real PV/diesel hybrid system without storage in the open literature, which justifies the interest of this study.

\section{Experimental}

\subsection{Experimental set up}

The hybrid systems can be broadly classified in series hybrid, switched hybrid and parallel hybrid configurations [14]. The present prototype has a parallel hybrid configuration (fig. 1). In this scheme, the PV system is parallel connected to the diesel generator by means of a DC-AC converter or inverter. The PV and the diesel generators supply a portion of the load demand directly.

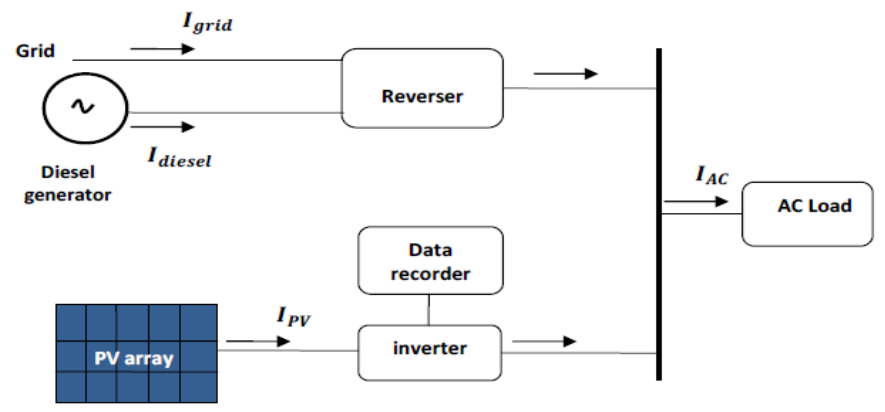

Figure 1: $\quad$ Prototype design.

The PV system is composed of 15 modules HIT (Heterojunction with Intrinsic Thin layer), each rated at $190 \mathrm{Wp}$, totalling $2.85 \mathrm{kWp}$ DC at Standard Testing Conditions (irradiance $=1000 \mathrm{~W} / \mathrm{m}^{2}$; Solar cell operating temperature $=25^{\circ} \mathrm{C}$ and $\mathrm{AM}=1.5$ ). The $\mathrm{PV}$ array covers an area of about $18 \mathrm{~m}^{2}$ with PV modules distributed in a parallel/series configuration of three module strings connected to one inverter rated at $3.82 \mathrm{~kW}$. The diesel generator rated power is $9.2 \mathrm{~kW}(11.5 \mathrm{kVA})$ of $1500 \mathrm{rpm}$.

\subsection{Experimental protocol}

Any general study over such a system should be done using first a set of hypothetic loads allowing the analysis of its performances and limitations. The consideration of typical loads in agreement with particular situations has to be done further in order to optimize the system. Then, in the present investigation, the load/demand profiles are treated as constant for the simulation of the hybrid system. Four load profiles have been considered $(3.7 \mathrm{~kW}, 5.7 \mathrm{~kW}, 7.6 \mathrm{~kW}$ and 
$9.7 \mathrm{~kW}$ ) corresponding to $40 \%, 62 \%, 82 \%$ and $105 \%$ of the nominal power of the diesel generator [15]. The demand profiles are experimentally simulated by two resistive bank loads of $4 \mathrm{~kW}$ each with different switches allowing by combination to reach the desired load. The mix of interdependent key parameters such as: The power generated by the PV array (depending of solar radiation), the power generated by the diesel generator and the specific/hourly consumption of the diesel generator to match the predefined load have been studied.

\section{Results and discussion}

\subsection{Diesel generator characteristics of the system studied}

A diesel generator (DG) is broadly characterized by its fuel consumption (the hourly consumption in $1 / \mathrm{h}$ or the specific consumption in $1 / \mathrm{kWh}$ ). According to Reinigher et al. [16], the hourly fuel consumption of a diesel generator can be approximated as follow:

$$
q(t)=a \cdot P(t)+b \cdot P_{r}
$$

where $a(1 / \mathrm{kW})$ and $b(1 / \mathrm{kW})$ are constants for a typical DG, $P_{t}(\mathrm{~kW})$ is the power generated by the diesel generator and $P_{r}(\mathrm{~kW})$ is its rated power. As shown in fig. 2, the relation (1) has been validated with the current fuel consumption data of a typical diesel generator of $9.2 \mathrm{~kW}$. The model coefficients obtained for these data are $a=0.2476 \mathrm{l} / \mathrm{kWh}$ and $b=0.0739 \mathrm{l} / \mathrm{kWh}$ with a coefficient of determination $\left(R^{2}\right)$ equal to 0.9895

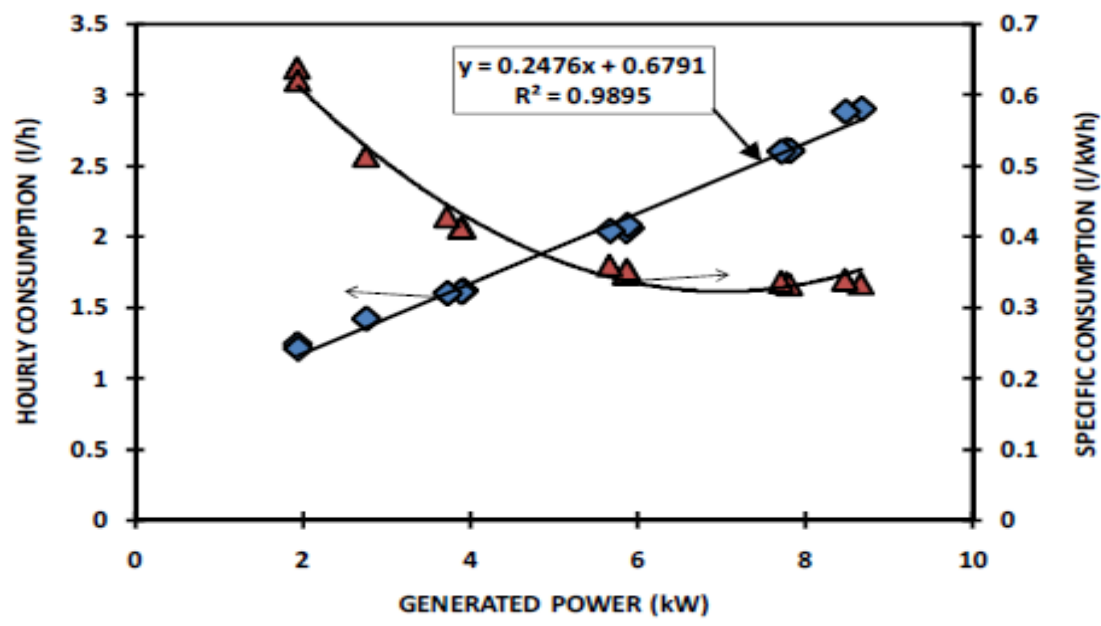

Figure 2: Fuel consumption of the diesel generator as a function of output power. 
Also, fig. 2 gives the specific fuel consumption of the diesel generator as a function of its power output. It can be noted that when the diesel generator operates near to $20 \%$ of its rated power, its specific consumption is too high (about $0.64 \mathrm{l} / \mathrm{kWh}$ ) corresponding to a low efficiency of the latter. However, the minimum specific fuel consumption of the diesel generator is about $0.3241 / \mathrm{kWh}$ and corresponds to about $80 \%$ of its rated power meaning that a higher fuel saving, thus a good efficiency, may be obtained if the diesel generator operates near this load fraction.

This result corresponds to what is stipulated by authors as Ashari et al. [17] and El-Hefnawi [18] saying that the diesel generator have typically a maximum fuel efficiency of about $0.331 / \mathrm{kW}$ when run above $80 \%$ of its rated power (for the first authors) and when it operates from 70 to $89 \%$ of its rated power (for the second author).

In the following section the behavior of the diesel generator in the hybrid system is thoroughly analyzed.

\subsection{Behavior of the hybrid system under different loads}

In this section, the behavior of a typical hybrid PV/diesel system without storage which characteristics have been presented in the previous sections is studied. The contribution of the PV and diesel generators, the specific consumption of the diesel generator for a given load $(L)$ profile have been assessed. As mentioned previously, for four days (which solar radiation curves are given in fig. 3), we have considered four constant load profiles $(3.7 \mathrm{~kW}, 5.7 \mathrm{~kW}, 7.6 \mathrm{~kW}$ and 9.7 $\mathrm{kW}$ ) corresponding respectively to $40 \%, 62 \%, 82 \%$ and $105 \%$ of the diesel generator nominal power.

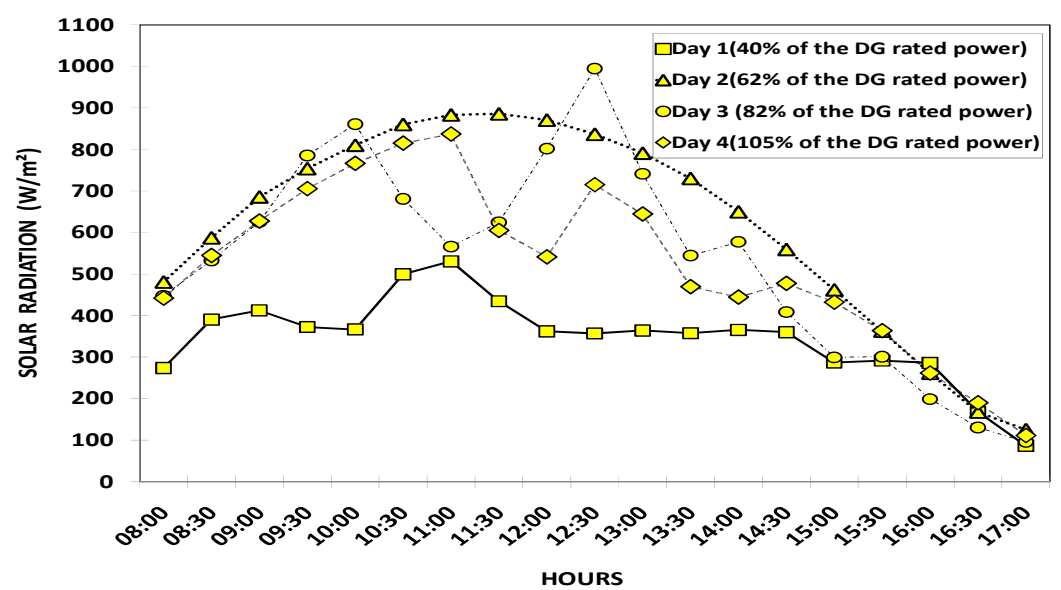

Figure 3: $\quad$ Solar radiation curves for the four days of the experiments.

The behaviors of the PV and diesel generators in the hybrid system are interdependent. Indeed, a given load is supplied as well by the diesel generator as by the PV generator. It can be observed from fig. 4 to fig. 7 that for the loads in 
the order mentioned above, the specific fuel consumption of the diesel generator ranges respectively between: 0.45 to $0.51 \mathrm{l} / \mathrm{kWh}$ (see fig. 4 ), 0.35 to $0.41 \mathrm{l} / \mathrm{kWh}$ (see fig. 5), 0.33 to $0.36 \mathrm{l} / \mathrm{kWh}$ (see fig. 6) and 0.33 to $0.34 \mathrm{l} / \mathrm{kWh}$ (see fig. 7).

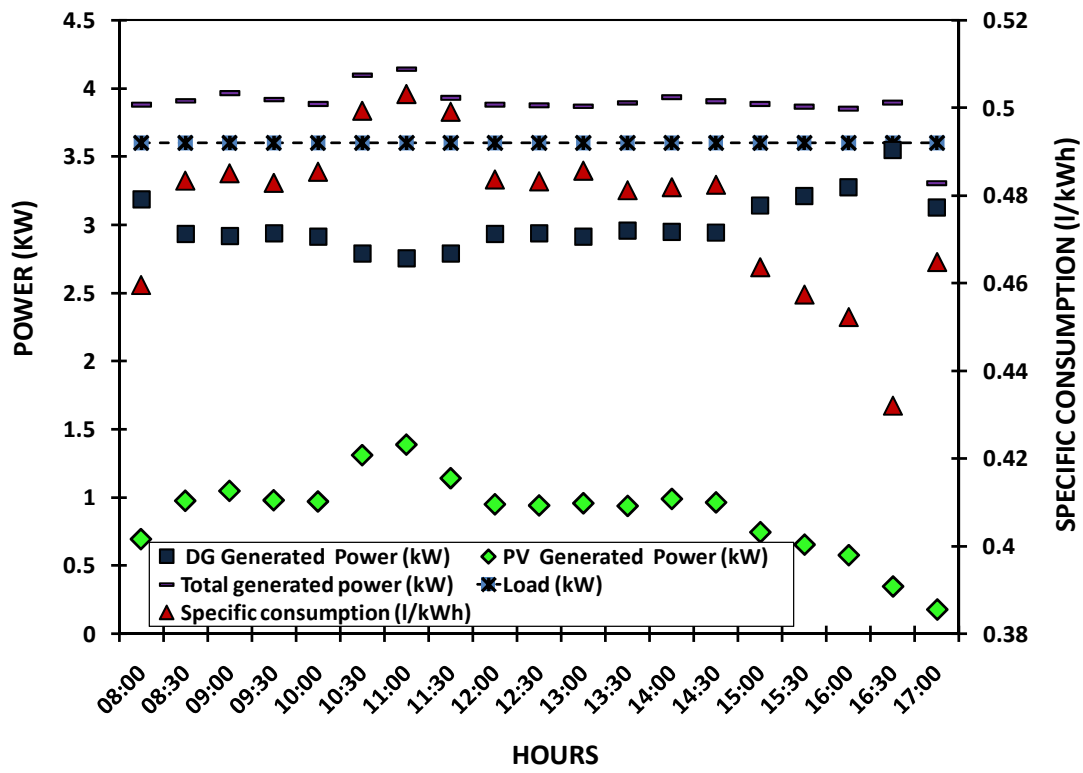

Figure 4: Behaviour of the system for a load representing $40 \%$ of the diesel generator rated power.

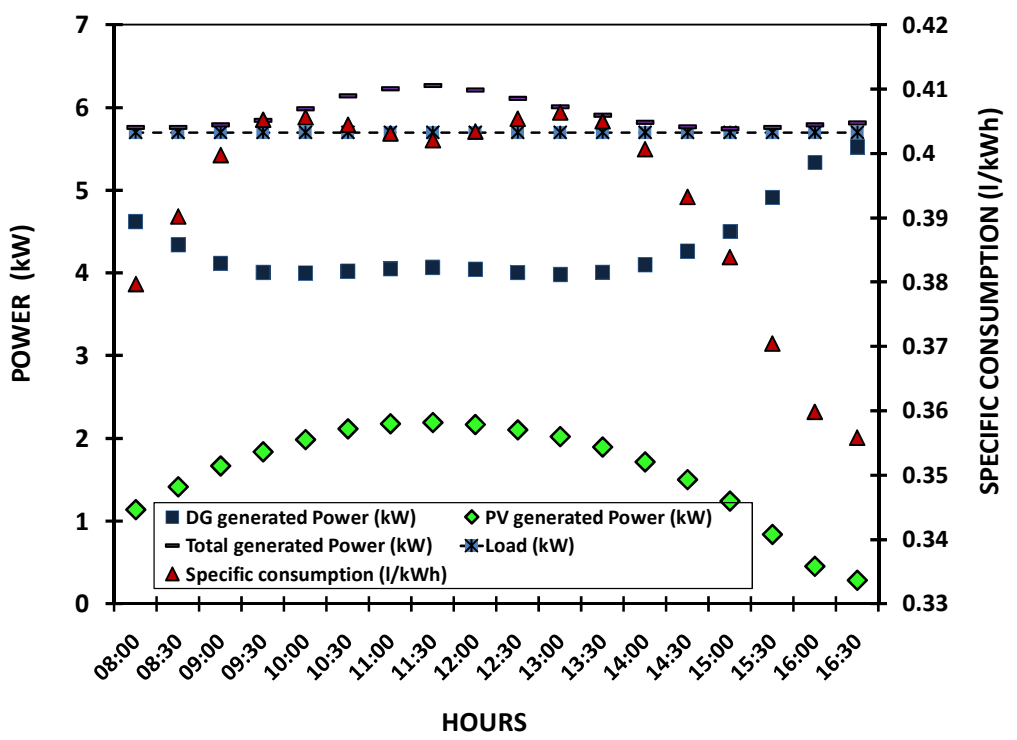

Figure 5: Behaviour of the system for a load representing $62 \%$ of the diesel generator rated power. 
These results show that for small loads (less than $62 \%$ of the rated power of the DG), the contribution of PV generator $\left(P_{A C} / L\right)$ which ranges between 4 to $38 \%$ for load values of $3.7 \mathrm{~kW}$ and $5.7 \mathrm{~kW}$ does not enable an optimal functioning of PV generator. In fact, as mentioned by Ashari et al. [17] and also verified by results obtained in the present investigation, the maximum fuel efficiency of a diesel generator is about $0.33 \mathrm{l} / \mathrm{kW}$, but for these two rated loads, the specific fuel consumptions are far from this optimal value. This is due to the fact that these loads are already far from the optimal functioning point of the diesel generator and therefore the PV generator contributes rather to decrease the performance of the engine.

However, for high loads (see fig. 6 and fig. 7), the contribution of the PV array which ranges between $1.5 \%$ and $33 \%$ for a load value of $7.6 \mathrm{~kW}$ and between $2.5 \%$ to $22 \%$ for a load value of $9.7 \mathrm{~kW}$ does not considerably affect the performance of the engine.

As a matter of fact, for these loads, the values of the specific fuel consumption vary between 0.33 to $0.36 \mathrm{l} / \mathrm{kWh}$ which is close to the optimal functioning point of the diesel generator.

As the specific fuel consumption and then the operation cost of the diesel generator increases considerably when the hybrid system operates below the load values representing less than $62 \%$ of the rated power of the DG, the sizing of the system must be done so that the diesel generator operates near its optimal point (70-90\% of its nominal power).

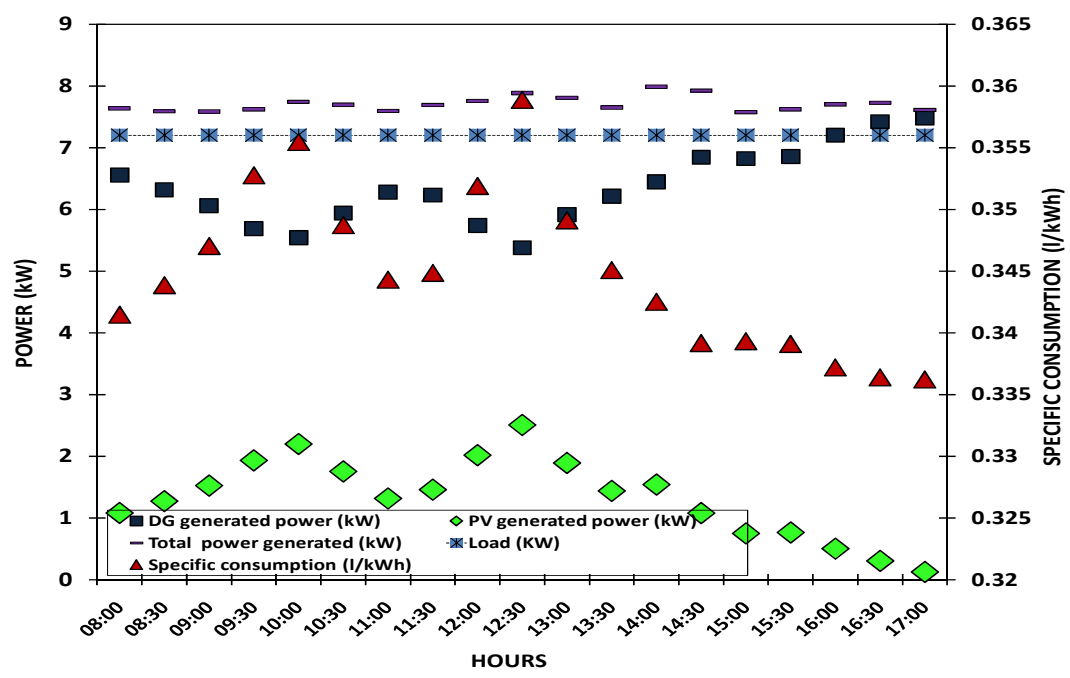

Figure 6: Behavior of the system for a load representing $82 \%$ of the diesel generator rated power. 


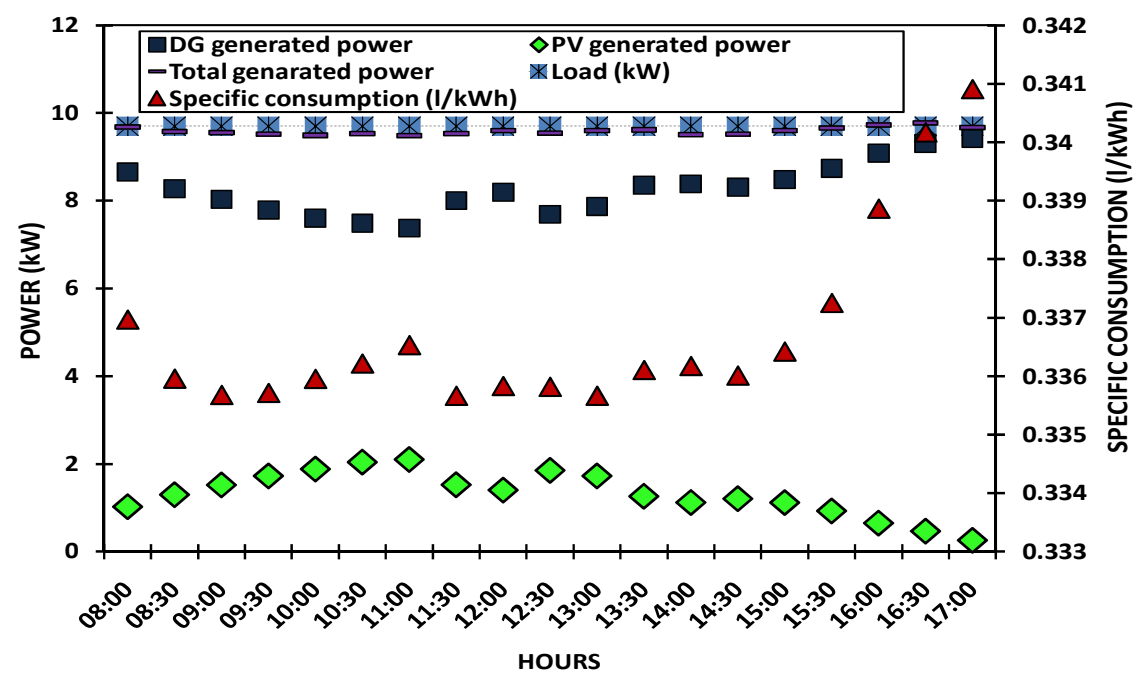

Figure 7: Behaviour of the system for a load representing $105 \%$ of the diesel generator rated power.

\subsection{PV Penetration level in the hybrid system}

The ratio of the real output power of the PV system on the maximum load $\frac{P_{P V}}{L}$ is a best indication about the contribution of the PV generator for a given load. As shown in fig. 8, the ratio $\frac{P_{P V}}{L}$ is a function of the solar radiation and loads. It can be observed that for lower loads $(3.7 \mathrm{~kW}$ and $5.7 \mathrm{~kW})$, one has a value of ratio $\frac{P_{P V}}{L}$ which ranges from 2 to $49 \%$ and from 2 to $33 \%$ respectively (for a solar radiation value varying between 150 and $950 \mathrm{~W} / \mathrm{m}^{2}$ ). However for high loads $(7.6 \mathrm{~kW}$ and $9.7 \mathrm{~kW})$, it can be observed that the value of ratio $\frac{P_{P V}}{L}$ varies from 3 to $26 \%$, and from 2 to $21 \%$ respectively for the same values of solar radiation.

But, it should be note that the high PV penetration is not a synonym of high efficiency of the PV system because for the close value of solar radiation, the power generated by the solar field is more important for the higher loads than for the lowers. In fact, one can see that for the close values of solar radiation, the production of PV generator is more important for the higher loads than for the lowers. This means that for an optimum production of the PV array, the ideal would be that the maximum solar radiation moments meet the peak load moments during a day. 


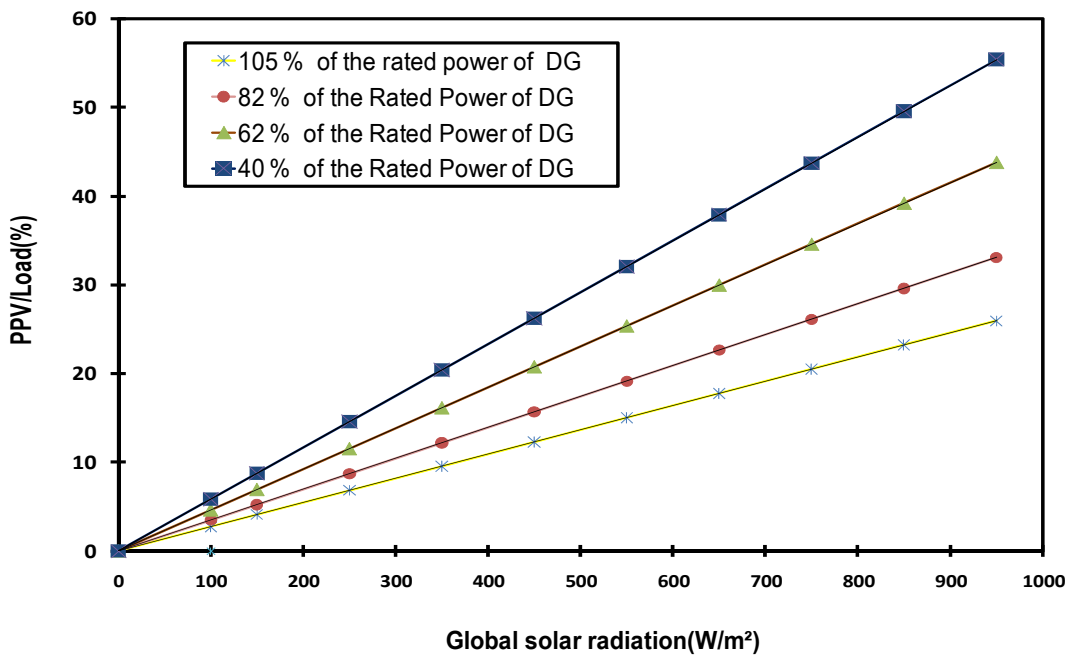

Figure 8: Contribution of PV generator for a given load in function of solar radiation.

Fig. 8 is also a good sizing tool for the hybrid system because for a given load and a given solar radiation value, one can have the power generated by the PV generator and then the PV array size needful for this production.

\section{Advantages of using hybrid systems: comparative analysis for three different systems (diesel generator only, solar PV generator only and hybrid solar PV/diesel) for powering a same load profile [3]}

To point out the economic advantages of hybrid systems for remote areas, a comparative analysis is conducted for the three types of power generators (DG only, PV generator only and hybrid solar PV/diesel) for powering the same load. It is well known that the load profile estimation is an important criterion for sizing and designing a power supply system. For this study a typical daily load of the Sabou village in Burkina Faso (located at south west of the country, $12^{\circ} 3 \mathrm{~N}$ and $21^{\circ} 3 \mathrm{~W}$ ) is considered (see fig. 9). This village has 45,000 inhabitants, thus about 6429 households (if considering seven persons per household).

The total daily need in energy of the village Sabou is $469 \mathrm{kWh}$ with a maximum power peak load of $35 \mathrm{~kW}$ and minimum power peak of $14 \mathrm{~kW}$.

\subsection{Evaluation of each power system size for the above load profile}

Considering the above load profile, one can evaluate the size of each power system (DG only, PV generator only and PV/diesel hybrid system). 


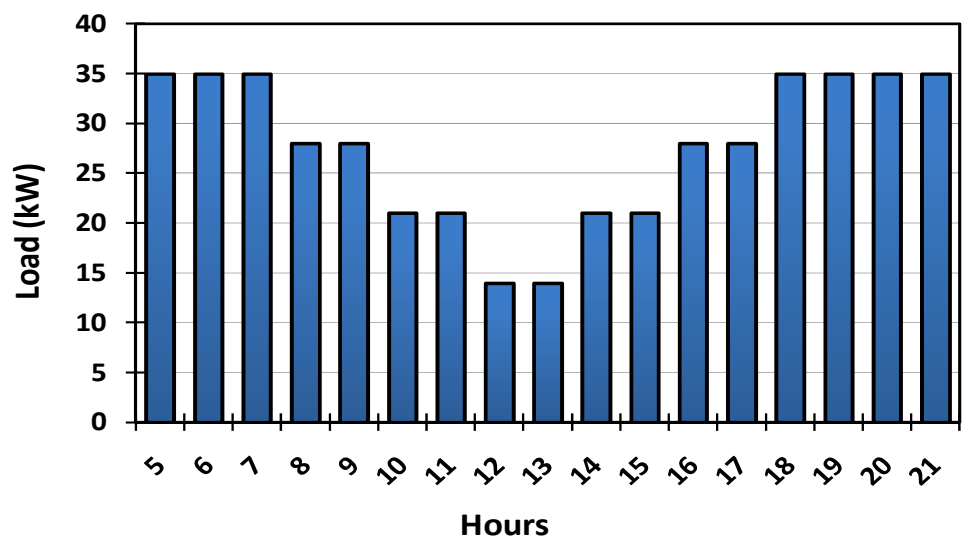

Figure 9: $\quad$ Typical daily load profile of the Sabou village in Burkina Faso.

\subsubsection{Size of diesel generator only}

For the sizing of the DG only, it has been considered that the optimal functioning point of this later is at $90 \%$ of its nominal capacity. Therefore, to satisfy the load profile at its peak load, the power of the DG only will be $38.5 \mathrm{~kW}$.

\subsubsection{Size of PV generator/batteries only}

To meet the same load profile using only a PV system, a PV array of $61 \mathrm{kWp}$ and a battery capacity of 41,037.5 Ah (for $12 \mathrm{~V}$ ) are needed.

\subsubsection{Size of PV/diesel hybrid system}

For a PV maximum penetration of $30 \%$ (generally chosen in hybrid system), one needs a PV array of about $18 \mathrm{kWp}$. The size of DG is taken as same as the DG only one $(38.5 \mathrm{~kW})$ because we assume that it must be able to meet the peak load in cases of low solar radiation, sudden clouds appearance and in the night.

\subsection{Economic analysis}

The economic analysis made in this section is based on the use of the life cycle cost (LCC). The life cycle cost is an economic assessment of the cost for a number of alternatives by taking into account all significant costs over the lifetime of each alternative, adding each option's costs for every year and discounting them back to a common base. These costs can be categorized into two types: (i) recurring cost (operation cost for the DG and maintenance cost for the DG, the PV generator and batteries) and (ii) non-recurring cost (batteries and DG replacement costs). The life cycle cost can be expressed as follows [13].

$$
L C C=C+P W_{R}+P W_{N R}-P W_{S}
$$


where $C$ is the initial cost. $P W_{R}, P W_{N R}$ and $P W_{S}$ are, respectively the present worth of the recurring costs, non recurring costs and salvage values. They are expressed by:

$$
\begin{gathered}
P W_{R}=R \frac{\left[\frac{1+e}{1+i}\right]\left\{\left[\frac{1+e}{1+i}\right]^{n}-1\right\}}{\left[\frac{1+e}{1+i}\right]} \\
P W_{N R}=N R \frac{\left[\frac{1+e}{1+i_{\text {adj }}}\right]\left\{\left[\frac{1+e}{1+i_{\text {adj }}}\right]^{n}-1\right\}}{\left[\frac{1+e}{1+i_{\text {adj }}}\right]} \\
P W_{S}=S \frac{1}{(1+i)^{n}}
\end{gathered}
$$

where $R$ is the recurring cost, $N R$ the non recurring cost, $S$ the salvage value, $n$ the lifetime of the whole system, $e$ the escalation rate, $i$ the discount rate and iadj the adjusted discount rate for the recurring cost and given by:

$$
i_{\text {adj }}=\frac{(1+i)^{P}}{(1+e)^{P-1}}-1
$$

\begin{tabular}{|c|c|c|c|}
\hline & $\begin{array}{l}\text { Diesel generator } \\
\text { system }(38.5 \\
\mathrm{kW})\end{array}$ & PV & Battery \\
\hline Initial cost $(€)$ & $15,400 €$ & $7000 € / \mathrm{kWp}$ & $0.07 € / \mathrm{Wh}$ \\
\hline Annual operation cost $(€)$ & $0.9 € / 1$ of oil & 0 & 0 \\
\hline Annual maintenance cost $(€)$ & $0.18 * \mathrm{RT}$ & $\begin{array}{l}3 \% \text { of } \\
\text { annualized } \\
\text { initial cost }\end{array}$ & $\begin{array}{l}15 \% \text { of } \\
\text { annualized } \\
\text { capital cost }\end{array}$ \\
\hline Salvage value $(€)$ & $\begin{array}{l}10 \% \text { of DG } \\
\text { initial cost }\end{array}$ & $\begin{array}{l}10 \% \text { of } \mathrm{PV} \\
\text { initial cost }\end{array}$ & 0 \\
\hline Replacement cost $(€)$ & $\begin{array}{l}\text { equal to initial } \\
\text { cost }\end{array}$ & 0 & $\begin{array}{l}\text { equal to initial } \\
\text { cost }\end{array}$ \\
\hline Life span (years) & 10 & 20 & 5 \\
\hline interest rate, $\mathrm{i}(\%)$ & \multicolumn{3}{|c|}{$8 \%$} \\
\hline escalation rate, $\mathrm{e}(\%)$ & \multicolumn{3}{|c|}{$4 \%$} \\
\hline
\end{tabular}

$P$ is the period between two successive payments for the non-recurring costs.

Table 1: Costing data considered in the present study. 
The life cycle cost analysis has been made using the data of table1. In table1, $\mathrm{RT}$ is the running time of the diesel generator. It has been consider that the consumption model of the diesel generator is like the one of section 4.1.

After calculation, one obtained that for the same energy demand estimated at 3,423,700 kWh over 20 years, hybrid solar PV/diesel system Life cycle cost (LCC $=983,865$ Euros) is lower than the PV generator only (LCC $=992,000$ Euros) which is at its turn lower than the DG only ( $\mathrm{LCC}=996,000$ Euros). It is important to point out that the hybrid system considered here is not the optimal one in terms of configuration, the load management, and even the whole system management. By considering all these aspects and especially the environmental aspect, it is no doubt that the benefits will be more important [3].

\section{Conclusion}

This paper presents in its first part, the experimental results of a hybrid PV/diesel system without storage. These results are very useful for the design optimization and the reliability enhancement of PV/Diesel hybrid systems. In the second part, the economical analysis made, shows that the hybrid systems could provide appropriate technological and cost-effective solutions for the electrification of rural and semi-urban areas.

\section{References}

[1] World Energy Outlook (WEO), www.iea.org/weo/electricity.asp.

[2] Barley, C.D., Optimal dispatch strategy in remote hybrid Power systems. Solar Energy, 58(4-6), pp. 165-179, 1996.

[3] Azoumah, Y., Yamegueu, D., Ginies, P., Coulibaly, Y. \& Girard, P., Sustainable electricity generation for rural and peri-urban populations of sub-Saharan Africa: the "flexy-energy" concept. Energy Policy, doi: 10.1016/j.enpol.2010.09.021.

[4] Deshmukha, M.K. \& Deshmukh, S.S., Modeling of hybrid renewable energy systems. Renewable and Sustainable Energy Reviews, 12, pp. 235249, 2008.

[5] Hochmuth, G.C.S., A combined Optimisation Concept for the design and operation strategy of hybrid-PV energy systems. Solar Energy, 61(2), pp. 77-87, 1997.

[6] Shaahid, S.M. \& El-Amink, I., Techno-economic evaluation of off-grid hybrid photovoltaic-diesel-battery power systems for rural electrification in Saudi Arabia-A way forward for sustainable development. Renewable and Sustainable Energy Reviews, 13, pp. 625-633, 2009.

[7] Ruther, R., Martins, D.C. \& Bazzo, E., Hybrid Diesel/Photovoltaic systems without storage for isolated mini-grids sin Northern Brazil. Proc. of the 28th IEEE Photovoltaic Specialists Conference: Anchorage, pp.1567-1570, 2000 . 
[8] Koutroulis, E., Kolokotsa, D., Potirakis, A. \& Kalaitzakis, K., Methodology for optimal sizing of stand-alone photovoltaic/wind-generator systems using genetic algorithms. Solar Energy, 80, pp. 1072-1088, 2006.

[9] Musseli, M., Notton, G. \& Louche, A., Design of hybrid-photovoltaic power generator, with optimization of energy management. Solar Energy, 65(3), pp. 143-157, 1999.

[10] Lopez, R.D. \& Agustin, J.L.B., Design and control strategies of PV-Diesel systems using genetic algorithms Rodolfo. Solar Energy, 79, pp. 33-46, 2005.

[11] Notton, G., Musseli, M., Poggi, P. \& Louche, A., Autonomous Photovoltaic systems influences of some parameters on the sizing: Simulation time step, Input and Output power profile. Renewable Energy, 1(4), pp. 353-369, 1996.

[12] Yang, H., Lu, L. \& Zhou, W., A novel optimization sizing model for hybrid solar-wind power generation system. Solar Energy, 81, pp. 76-84, 2007.

[13] Ajan, C.W., Ahmed, S.S., Ahmad, H.B., Taha, F. \& Zin, A.A.B.M., On the policy of photovoltaic and diesel generation mix for an off-grid site: East Malaysian perspectives. Solar Energy, 74, pp. 453-467, 2003.

[14] Nayar, C.V., Recent developments in decentralised mini-grid diesel power systems in Australia. Applied Energy, 52, pp. 229- 242, 1995.

[15] Yamegueu, D., Azoumah, Y., Py, X. \& Zongo, S.J., Experimental study of electricity generation by Solar PV/Diesel hybrid systems without battery storage for off grid areas, Renewable Energy(accepted for publication), 2010.

[16] Skarstein, O. \& Uhlen, K., Design considerations with respect to long-term diesel saving in wind/diesel plants. Wind Engineering, 13, pp. 72-87, 1989.

[17] Ashari, M. \& Nayar, C.V., An optimum dispatch strategy using set points for a Photovoltaic (pv)-diesel-battery hybrid power system. Solar Energy, 66(1), pp. 1-9, 1999.

[18] El-Hefnawi, S.H., Photovoltaic diesel-generator hybrid power system sizing. Renewable Energy, 13(1), pp. 33-40, 1998. 